\title{
Entrepreneurial Competencies and Entrepreneurial Orientation of Tea Manufacturing Firms in Sri Lanka
}

\author{
Aruni Wickramaratne ${ }^{1,2}$, Akira Kiminami ${ }^{1} \&$ Hironori Yagi ${ }^{1}$ \\ ${ }^{1}$ Department of Agriculture and Resource Economics, Graduate School of Agriculture and Life Sciences, The \\ University of Tokyo, Japan \\ ${ }^{2}$ Department of Agricultural Economics, Faculty of Agriculture, University of Ruhuna, Matara, Sri Lanka \\ Correspondence: Aruni Wickramaratne, Department of Agriculture and Resource Economics, Graduate School \\ of Agriculture and Life Sciences, The University of Tokyo, 1-1-1-323A, Yayoi, Bunkyo-ku, Tokyo 113-8657, \\ Japan. Tel: 81-3-5841-5321. E-mail: aruni_dpw@yahoo.com
}

Received: May 20, 2014 Accepted: July 10, 2014 Online Published: August 15, 2014

doi:10.5539/ass.v10n18p50 URL: http://dx.doi.org/10.5539/ass.v10n18p50

\begin{abstract}
Throughout the past few decades, significance of entrepreneurial competencies has been amplified due to the strategic role take part by the entrepreneur of a business enterprise. Therefore, the aim of the study is to examine the impact of owner/managers entrepreneurial competencies on Entrepreneurial Orientation (EO) of tea manufacturing firms in Sri Lanka and the relationship between background characteristics of owner/managers and entrepreneurial competencies. Primary data was collected in low country tea manufacturing firms in Sri Lanka. The sample includes 109 private sector tea factories. Entrepreneurial competencies were operationalized as opportunity, organizing, strategic, relationship, commitment and conceptual competencies. Data were analyzed by using multiple regression analysis. It was found that background characteristics of owner/managers have direct impact on entrepreneurial competencies. Further it implies that entrepreneurs strategic and commitment competencies have direct positive relationship with EO. When considering the dimensions of EO, innovativeness was greatly affected by owner/managers competencies whereas risk taking behavior was less affected by competencies. Hence, findings of the present study would be essential for owner/managers and strategy makers to enhance the EO of tea manufacturing firms in Sri Lanka towards global competition in the tea industry by knowing what competencies are crucial for EO.
\end{abstract}

Keywords: background characteristics, entrepreneurial competencies, entrepreneurial orientation (EO), Sri Lanka, tea manufacturing firms

\section{Introduction}

The Sri Lankan tea industry is playing predominant role in the economy. Its high foreign exchange earning capacity has permitted the country to rely great extent on the tea industry. But at present, the Sri Lankan tea industry is facing some challenges as; increasing the production cost, deficiencies of productivity in factory and field level, rising competition of newly emerging low cost producer countries (Mohamed \& Zoysa, 2006) and increasingly incline the global consumption patterns towards more convenient types of this beverage. Accordingly, it is essential to look for new opportunities since uncertainty of the future profit flows from on hand operations. Therefore, tea manufacturing firms possibly will advantage from adopting an "entrepreneurial orientation" (EO). This explains the firm's motivation to innovate new market offerings, being more proactive for new marketplace opportunities than rival firms, and testing new and uncertain products and markets by risk taking (Covin \& Slevin, 1989).

The environment is becoming ever more complex where the tea manufacturers are work today. Therefore, in order to diminish the negative consequence of the challenging business environment it is important that the entrepreneurs act proactively with the environment. Entrepreneurial competencies are becoming more important in order to take such proactive move towards the environment. During past few decades significance of entrepreneurial competencies has been increased due to the strategic role take part by the entrepreneur of a business enterprise. In practically, different levels of entrepreneurial competencies are revealed by entrepreneurs who found the business or add value through their effort (Bird, 1995). The hypothetical link between competencies and start, survival and growth of business implies the interest of entrepreneurial competencies 
(Bird, 1995).

One way of inspiring the economic growth of developing nations is supporting for entrepreneurial activities (Harper, 1991). This has led the Sri Lankan government to place emphasis on programs and policies to develop the tea industry. Although, the efficiency of these policies and programs are depend on a thorough understanding of owner/managers and how they operate. Of particular importance are owner/managers competencies. Man et al. (2002) mentioned that the most influential factors of small and medium sized enterprises performance are entrepreneurial characteristics such as, attitudinal, behavioral, managerial and technical competencies. Additionally Miller and Toulouse (1986b) found that strategic orientation of a business firm is affected by the influence of the chief executive officer (CEO). Further, business strategies are largely depending on entrepreneur's personal competencies (Morris et al., 2005). Therefore, this study focuses on the entrepreneurial competencies which required carrying the business successfully.

In this study, entrepreneur is described as the person behind the booming strategic orientation and competency is defined as the abilities required accomplishing the business successfully. The competency approach is used to determine the influence of an entrepreneur through behavioral perspective. The total capability of entrepreneurs' to perform the job role successfully is described as entrepreneurial competencies by Man et al. (2002). Additionally, competencies can be seen as behavioral and noticeable (Bird, 1995). As a result, competencies are learnable and possible to change. Therefore, it allows interference in term of the training and development of entrepreneurial process.

Entrepreneurs are challenged to set up their competencies in order to succeed in entrepreneurial actions. In the entrepreneurial literature discussion of competencies still in its early stage (Brinckmann, 2008). At present, a few researches have been conducted to identify the relationship between managerial or entrepreneurial competencies and performance of the firm (e.g. Chandler \& Jansen, 1992; Chandler \& Hanks, 1994; Man et al., 2008). Hence further statistical validation is clearly the way ahead (Man et al., 2002). Further, according to Porter (1991), management will always have some authority on strategy and he explained that eventually, managers can generate and carry on competitive advantage by the constant innovation and upgrading of resources. It is still rare empirical studies which examine the link between owner/manager competencies and EO. This is the research gap seeks to fill by examining how entrepreneurial competencies influence on EO and its dimensions of proactiveness, innovation and risk taking in developing economic context.

In this paper we examine the competencies of owner/managers of low country tea manufacturing firms in Sri Lanka in six competency areas as opportunity, organizing, strategic, relationship, commitment and conceptual competencies, antecedents of entrepreneurial competencies and extent of EO of tea manufacturing firms. Specifically, the objective of this paper is to study the impact of owner/managers competencies on EO of tea manufacturing firms in Sri Lanka. By addressing following research questions this study attempts to contribute the literature. (1) what is the relationship between owner/managers background characteristics and entrepreneurial competencies. (2) to what extent do entrepreneurial competencies have an impact on overall EO and the dimensions of EO.

This study enrich the entrepreneurship literature by providing empirical data on impact of entrepreneurial competencies of owner/managers on EO and its dimensions of tea manufacturing firms. Further, studies of entrepreneurship in the Sri Lankan tea industry are rare and still in a growth stage. Hence, such contributions are important to owner/managers and policy makers to enhance the EO towards global competition in the tea industry by knowing what competencies are crucial for EO.

\section{Theoretical Background and Hypotheses}

\subsection{Entrepreneurial Competencies}

In a competitive business environment, the entrepreneurs are needed to be well competent in different areas such as attitudinal, intellectual, behavioral and managerial since the business process is considered to be very composite today. Therefore, role of entrepreneur in business venture is considered as curtail and it is studied through the competency approach. As a way of studying entrepreneurial characteristics, the competency approach has become popular (e.g. Bird, 1995; Chandler \& Jansen, 1992; Men et al., 2002; Schmitt-Rodermund, 2004). Bird (1995) defined entrepreneurial competencies as primary characteristics such as basic and specific knowledge, motives, traits, self-image, roles and skills which required for business startup, survival and/or growth. Further she suggested competencies can be seen as behavioral and observable. Thus it can be learnable and possible to change through intervention such as selection and teaching of entrepreneurship (Man et al., 2002). The nature of entrepreneurial competencies indicated it as an important concept for improving entrepreneurship. 
Additionally, previous researches have attempted to categorize these entrepreneurial characteristics into means of competency areas. Huck and McEwen (1991) found that most vital competency areas for Jamaican entrepreneurs are planning and budgeting, and marketing. Whereas, Chandler and Jansen (1992) emphasized that capability of identify and forecast taking advantage of opportunities and make to see firm creation through to end results are two competencies that essential for entrepreneurial role. By viewing the real behavior of an entrepreneur, the characteristics of entrepreneurial competencies can be investigated from process perspectives. Man et al. (2002) defined the entire capability of the entrepreneur to execute the job role fruitfully as the entrepreneurial competency and their work identified six major competency areas as; opportunity, organizing, strategic, relationship, commitment and conceptual competencies. We exploit this categorization of entrepreneurial competencies for current study because of its comprehensiveness.

Brief descriptions of these competencies are as follows; according to Man et al. (2002) opportunity competencies are relate to identify and developing market opportunities through different ways. Chandler and Jansen (1992) implied that the skill to spot and visualize taking advantage of opportunities as one of most vital entrepreneurial roles. Further, Shane and Venkataraman (2000) proposed that crucial notions of entrepreneurship are opportunity recognition and utilization. Man et al. (2002) defined that competencies associated to the organization of diverse internal and external human, physical, financial and technological resources as organizing competencies. Further Chandler and Jansen (1992) found the implication of managerial tasks of an entrepreneur in human competence. Organizing competencies are generally alike to the managerial competencies recognized in the literature. Entrepreneurs need to set the direction for whole company as the owner/manager. Man et al. (2002) describes setting, evaluating, and executing the strategies of the firm as strategic competencies. These competencies are comparable to strategic management; according to David (2013) it involves 1) setting mission, 2) define objectives based on this mission, subsequent an internal and external analysis, 3) originating strategy to accomplish these objectives, and 4) executing and appraising the strategy.

According to Man et al. (2002) relationship competencies speak about to interactions, e.g., cooperation with environment, using relations, persuasive ability, communication and interpersonal skill. As described by Bird (1995) the relationship building is considered as entrepreneurial bonding, which comprises relationship making and reforming. Having strong competency in committing, determining and taking positive actions towards their responsibilities and tasks is characterized by successful entrepreneurs. This equivalent to the entrepreneurial role of drive to see end results of the firms (Chandler \& Jansen, 1992). Accordingly, Man et al. (2002) defined commitment competencies as the forces that entrepreneur to progress in advance with the business. Divers conceptual talents that are reflected in the entrepreneurial behaviors that are decision skills and consideration of complex information is described as conceptual competencies by Man et al. (2002). Further, Bird, (1995) express that ability in making cognitive and analytical thinking, learning, problem solving, sustaining temporal tension, and dealing with uncertainty are belong to this category.

\subsection{Antecedents of Entrepreneurial Competencies}

This study seeks to distinguish the influence of the antecedents of entrepreneurial competencies that have received attention in the entrepreneurship literature. It is important to observe education, previous work and industry experience as aspects that could influence the progress of entrepreneurial competencies (Bird, 1995). Maxwell and Westerfield (2002) argued that level of formal education and previous managerial experience influenced on the entrepreneur's innovativeness, which is part of competencies. Further, Krueger and Brazeal (1994) mentioned that prior work experience could potentially improve skills and abilities of entrepreneurs mostly in identifying business opportunities. However, there is only little research that empirically observes the antecedence of entrepreneurial competency. For example, Chandler and Jansen (1992) found that education level of the business founder slightly contribute to the progress of own competencies while, self-assessed entrepreneurial competencies are not related with prior experience as founder. Based on these arguments, this study examines the influence of antecedence on entrepreneurial competencies of the owner/manager.

\subsection{Outcomes of Entrepreneurial Competencies}

Most of previous research empirically explored the relationship between entrepreneurial competencies and the performance of business firms (Chandler \& Jansen, 1992; Chandler \& Hanks, 1994; Baum et al., 2001). Further, some models were proposed by Herron and Robinson (1993) and Man et al. (2002) to clarify relationship of entrepreneurial competencies and performance. Previous studies have focused on identifying which skills are essential for successful entrepreneurial action; e.g., Chandler and Jansen (1992) have proposed that core of entrepreneurial competency is comprise the ability to recognize and pursue an opportunity. Specifically Chandler and Hanks (1994) emphasized that gaining entrepreneurial competencies requires entrepreneurs to accomplish 
the ability to spot and pursue distinctive opportunities and the capability to utilize the resources needed to be able to do so successfully. Further, Westerberg et al. (1997) suggested that CEOs importance in obtaining and developing knowledge, skills and abilities vital to a firm's success. Some scholars have empirically identified the significant relationship between entrepreneurial competencies and firm performance. Chandler and Jansen (1992) investigated that founder's self-assessed entrepreneurial competencies have positive relationship with firm's growth. Chandler and Hanks (1994) also found growth of a business enterprise was directly correlated with the entrepreneurial competencies. Further, study of Baum et al. (2001) found that industry skill and technical skill which known as CEOs definite competencies have significant direct impact on growth of business, while organizational skill and opportunity recognition skill named as CEOs' general competencies have significant indirect influence on business enterprise growth.

\subsubsection{Entrepreneurial Competencies and EO}

Bird (1995) argues that critical factors of achieving the entrepreneurial success are outward look toward future, strategic focus and intentional postures. Further entrepreneurs make decisions about their entrepreneurial action depend on the judgments of their competencies. Therefore, it can be argued that competencies become critical in attaining better performance and/or success of a business firm (Bird, 1995; Chandler \& Hanks, 1994). Increased levels of competencies do not automatically result in capability. Bird (1995) proposes that highly effective entrepreneurs are those that go beyond launch into business survival and growth and competencies essential to start on a venture or carry out a business idea may be visualized as "baseline". Some empirical studies have verified that CEO's personality behavior have vital impact on the decision making process and more or less directly on the firms strategic orientation (Miller \&Toulouse, 1986 a, b; Miller et al., 1982). Further, Kotey and Meredith (1997) found that strategic orientation of a business was corresponded to certain profiles of personal values.

\subsection{Research Model and Hypotheses}

Based on the above literature, we suggest that entrepreneurial competencies of owner/manager impact on the entrepreneurial orientation of the firm. Therefore, the influence of the owner/manager is considered as critical and this is address through the competency approach. The present study describes individual characteristics that include both attitudes and behaviors as the entrepreneurial competencies, which permit entrepreneurs to achieve and maintain business success (Bird, 1995). Operationally, the categorization of entrepreneurial competencies by Man et al. (200) is utilized in this study. Namely, there are; opportunity, organizing, strategic, relationship, commitment and conceptual competencies. While the owner/managers experience, education, training, age can be seen as the antecedent of entrepreneurial competencies. Figure 1 explains the relationship between entrepreneurial competencies and EO.

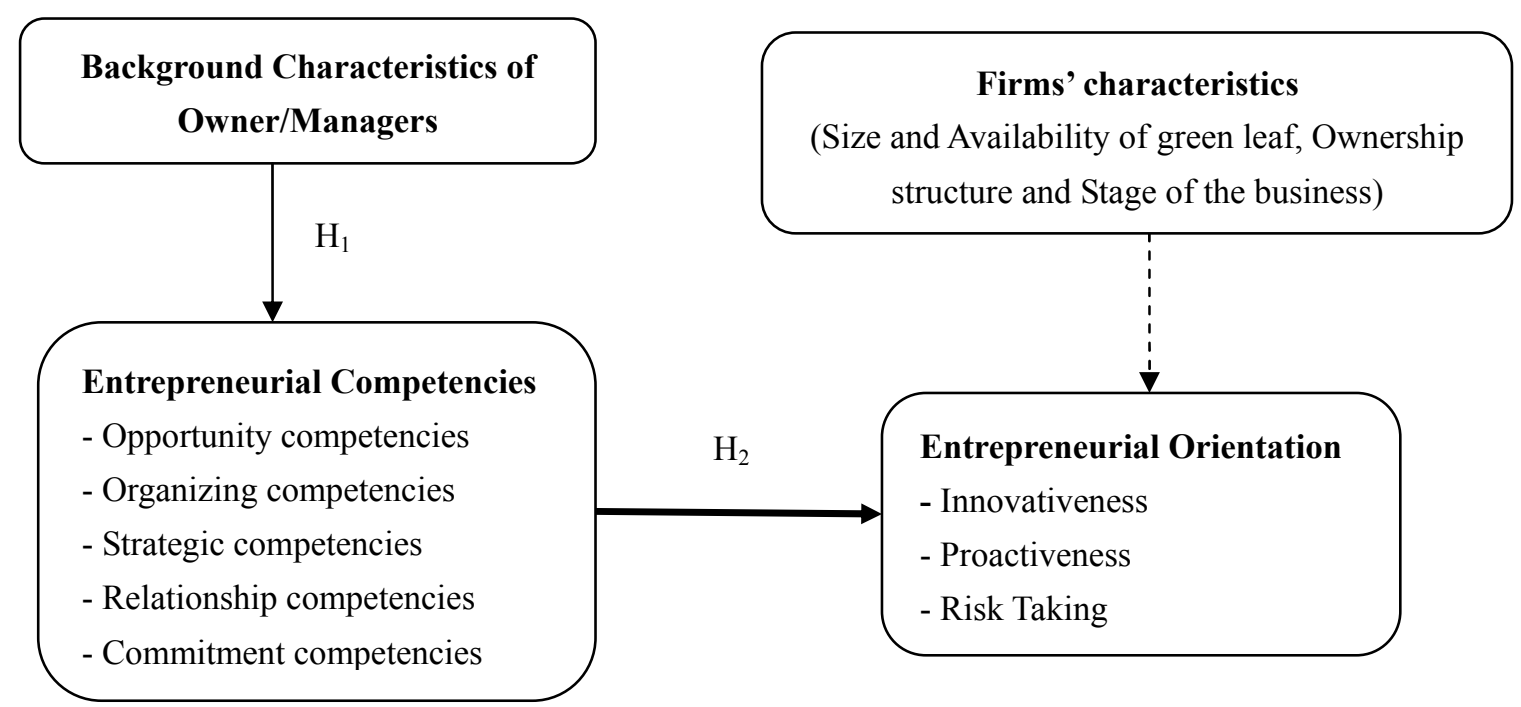

Figure 1. Research model

One way of improving entrepreneurial success is improving competencies. It implies that by utilizing owner/managers competencies properly can plan and work towards a firm's long term performance by adjusting entrepreneurial competencies which imitate motivation to innovate to new market offerings, be more proactive 
than rival firms for new market opportunities and take risks to test uncertain products and markets. The firms can hardly survive in fierce competition where those owner/managers are not capable enough. We propose the following hypothesis based on this argument;

\section{$H_{1}$ : Background characteristics of owner/managers have direct impact on entrepreneurial competencies}

$\mathrm{H}_{2}$ : The entrepreneurial competencies of owner/manager are positively related to the entrepreneurial orientation of tea manufacturing firms in Sri Lanka.

\section{Materials and Method}

\subsection{Sample and Data Collection}

To examine the influence of entrepreneurial competencies on EO of tea manufacturing in Sri Lanka, this research was performed in selected low elevation tea manufacturing firms, where having highest contribution $(60 \%$ in 2011$)$ to the total tea production comparing to high and mid elevations. Higher value of low grown specialty tea is mainly attributed for premier prices for Sri Lankan teas other than its quality factors. Firstly, we selected four main districts name Rathnapura, Galle, Matara and Kaluthara where gives highest contribution for low elevation production. Sample was taken from each district proportionately depend on the number of tea factories in each district and depend on the willingness of owner or manager of firm to be interviewed.

Total 422 tea factories are registered at Sri Lanka tea board under low elevation. Purposive sampling method was adopted in this research. Because sample selected in this research should fulfill two criteria. First, firm should be a private sector tea factory. Since, Sri Lanka tea board was categorized the tea factories as private sector, plantation companies, Janatha estates and state plantation corporation, and Tea Shakthi factories based on their management structure. Second, factory should be established more than five years. According to Hambrick (1981) self-reported perception of business owner/managers were used by entrepreneurship researchers since those individuals are usually quite knowledgeable about company strategies and business situation. Therefore, the respondents involved this research comprised of 109 owner/managers. Off 109 respondents, 30, 30, 39, 10 were collected from Rathnapura, Galle, Matara and Kaluthara districts respectively.

Primary data was collected by direct interviews with pre tested structured questionnaire. Since respondents were unwilling to provide information through other communication methods such as mail survey. To confirm the understandability and content validity of the survey instrument pilot study was carried out with owner/managers of four tea factories in study area.

\subsection{Measurements and Data Analysis}

All measures of entrepreneurial competencies and EO dimensions variables were drawn from the literature. In order to measure the entrepreneurial orientation we used three dimensions as innovativeness, proactiveness and risk taking which had been used in previous EO studies (e.g., Kreiser et al., 2002; Knight, 1997). Nine item scales developed and tested for reliability by Covin and Slevin (1989) was used to measure the EO by using five point Likert scales ranging where $1=$ strongly disagree to $5=$ strongly agree.

Entrepreneurial competencies were operationalized as opportunity, organizing, strategic, relationship, commitment and conceptual competencies as categorized by Man et al. (2002). The measures used in this research were estimated to be behavioral in nature. Accordingly, the measures were selected and customized from survey tool developed by Man (2001). Previous researches that conducted in relation to entrepreneurial competencies were asked respondents to self-assess their own competencies (Chandler \& Jansen, 1992; Chandler \& Hanks, 1994; Lerner \& Almor, 2002). Therefore, this approach was adapted in the present study. Competencies were measured using a five point Likert scale ranging from $1=$ strongly disagree to $5=$ strongly agree.

As an indicator of internal consistency and reliability of the scales, coefficient alpha was calculated. It was revealed that all scales had coefficient alpha greater than 0.70 levels except relationship competencies. It implies that the reliability of the measurements was achieved as recommended by Nunnally (1978). Based on the results of Pearson correlation analysis, significant relationships among variables were established. Proposed hypotheses were tested by using multiple regression analysis.

\section{Results and Discussion}

\subsection{Profile of Respondents}

In this section we would like to describe the background characteristics of respondents and the profile of tea manufacturing firms in low country Sri Lanka in this research (Appendix A). Respectively, 29\% and 71\% of respondents were owners and managers of tea manufacturing firms. Approximately $62 \%$ of the respondents were 
between 36 to 55 years old. Education level of the respondents indicated that $77 \%$ have advance level qualification whereas $15 \%$ have University degrees. When considering the training received by the owner/manager, $71 \%$ of them receive managerial or technical or both kind of training before they became to the current position. Whereas $40 \%$ of them were receive such training after them becoming owner/manager. Considering the prior business experience of the entrepreneurs, only $26 \%$ were having business start-up experience prior to the current business. The results showed that $48 \%$ of the entrepreneurs have been involved in other business. Moreover, $86 \%$ of these businesses are related to the tea industry. In terms of firm size, $57 \%$ of firms produce $25001-75000 \mathrm{~kg}$ of made tea per month while only $12 \%$ produce less or equal $25000 \mathrm{~kg}$ of tea. Ownership structure of tea manufacturing firms indicated that $43 \%$ of the firms were sole proprietorship, $36 \%$ were limited liability companies and $21 \%$ were partnership. In low country tea industry, $64 \%$ of the respondents consider their industry in the growing stage while only $4 \%$ in the declining stage.

\subsection{Antecedents of Entrepreneurial Competencies}

Table 1 presented the descriptive statistics of variables which were used for analysis for informational purpose. In this section, the impact of the personal and background characteristics of owner/manager on entrepreneurial competencies and EO are investigated by using multiple regression analysis and the results are shown in Table 2. The results revealed that present age of owner/manager was negatively effect on organizing and commitment competencies because with age entrepreneurs have a propensity to become less entrepreneurial (Cragg \& King, 1988). Man et al. (2008) also found that firms' competitive scope and performance tend to negatively impacted by present age of the entrepreneurs. Theoretically argues that education affects entrepreneurial ability. But, somewhat mixed results were found in empirical level regarding the relationship between entrepreneurial ability and education. Some researchers were found there is no significant relationship between education and entrepreneurial performance (Watanabe, 1970; Dyke et al., 1992) and significant negative relationship with performance (Stuart \& Abetti, 1990). Present study also found significant negative relationship with education level and opportunity competency of owner/manager. It is noticeable that influence of education varies depending on the nature of the industry. The present finding may be simply due to the nature of the industry since tea is not a high-tech industry.

Table 1. Descriptive statistics

\begin{tabular}{|c|c|c|c|c|}
\hline Variables & Minimum & Maximum & Mean & Std. Deviation \\
\hline Entrepreneurial Orientation & 16 & 45 & 32.94 & 6.890 \\
\hline Innovativeness & 3 & 15 & 9.27 & 2.990 \\
\hline Proactiveness & 6 & 15 & 12.14 & 2.481 \\
\hline Risk taking & 3 & 15 & 11.54 & 2.949 \\
\hline Opportunity competencies & 8 & 15 & 11.58 & 1.983 \\
\hline Relationship competencies & 19 & 25 & 22.21 & 1.769 \\
\hline Concept competencies & 10 & 24 & 19.86 & 3.113 \\
\hline Organizing competencies & 24 & 35 & 30.08 & 3.000 \\
\hline Strategic competencies & 29 & 38 & 31.84 & 2.495 \\
\hline Commitment competencies & 11 & 20 & 16.86 & 1.988 \\
\hline Present age & 25 & 85 & 46.66 & 11.334 \\
\hline Education level & 1 & 4 & 2.09 & .553 \\
\hline *Prior Training ${ }^{\mathrm{a}}$ & 0 & 1 & .71 & .458 \\
\hline * Training $^{\mathrm{b}}$ & 0 & 1 & .40 & .493 \\
\hline *Prior business experience & 0 & 1 & .26 & .439 \\
\hline *Having other business & 0 & 1 & .48 & .502 \\
\hline *Respondent-Owner & 0 & 1 & .29 & .458 \\
\hline Size (Lnmonthly sales) & 9 & 13 & 10.89 & .590 \\
\hline Availability of green leaf ${ }^{c}$ & 238 & 277 & 258.19 & 14.464 \\
\hline *Ownership-Sole proprietorship & 0 & 1 & .43 & .498 \\
\hline *Ownership-Partnerships & 0 & 1 & .21 & .410 \\
\hline *Development Stage-Maturity & 0 & 1 & .21 & .410 \\
\hline
\end{tabular}

Note: * Dummy variables, ${ }^{\mathrm{a}}$ Training received by owner/manager prior becoming the current position; ${ }^{\mathrm{b}}$ Training received by owner/manager after becoming the current position; ${ }^{c}$ Extent of tea cultivation in district (ha)/Number of tea factories in each district. 
The results illustrated that training received by owner/managers was significantly impacted on all competency areas considered in this study. Whereas prior training was significantly effected on relationship and organizing competencies. The common ground of these training is that they are directly related the development of business skills and knowledge and therefore, enhance the above mentioned entrepreneurial competencies of owner/managers. Further, study conducted by Alarape (2007) in small business found that owner-managers who had obtained entrepreneurship training have demonstrated comparatively better managerial performance than owner-managers who had not received training programs. This implies that training is crucial for enhance the entrepreneurial competencies of owner/manager.

When considering the prior business start-up experience of entrepreneurs, the results revealed that it have no significant relationship with competencies. Similar result was found by Chandler and Jansen (1992) that self-assessed entrepreneurial competencies were not significantly related to the prior business experience as founder. That may due to application of a particular experience vary in diverse situations such as in different industries. Further, Covin et al. (1990) found that different industries required different forms of management practices. According to the results, entrepreneur involvement in other business significantly impacted on opportunity, relationship, organizing and strategic competencies. The relationship between entrepreneurial competencies and involvement in other business is able to clarify by the reality that competent entrepreneurs have propensity to operate other business too. The results showed that the characteristics of owners were significantly impacted on all entrepreneurial competencies considered in this study except conceptual. It implies that normally managers possessed comparatively lower level of entrepreneurial competencies than owners of a business. A similar result was found by prior research conducted by Li (2009). Further, research on need for achievement found that comparatively managers have fewer morals in need for achievement than business owners (McClelland, 1965).

According to the results of Table 2, as proposed by hypothesis $1\left(\mathrm{H}_{1}\right)$, one or more background characteristics such as present age, educational level, prior training, training, having other business and respondent-owners significantly impacted on competencies considered in the study. Therefore, this research result supports hypothesis 1. This findings in line with the Bird's (1995) model which suggested that the personal and background characteristics are antecedent of entrepreneurial competencies.

Table 2. Regression results of owner/managers characteristic and entrepreneurial competencies

\begin{tabular}{|c|c|c|c|c|c|c|c|}
\hline \multirow{2}{*}{$\begin{array}{l}\text { Dependents } \\
\text { Independents }\end{array}$} & \multicolumn{6}{|c|}{ Entrepreneurial Competencies } & \multirow{2}{*}{ EO } \\
\hline & Opportunity & Relationship & Concept & Organizing & Strategic & Commitment & \\
\hline \multirow{2}{*}{ Present age } & -.050 & -.082 & -.028 & $-.198^{* *}$ & -.101 & $-.232 * *$ & -.122 \\
\hline & $(-.562)$ & $(-.892)$ & $(-.286)$ & $(-2.179)$ & $(-1.140)$ & $(-2.509)$ & $(-1.201)$ \\
\hline \multirow{2}{*}{$\begin{array}{l}\text { Education } \\
\text { level }\end{array}$} & $-.183 * *$ & -.093 & .030 & -.061 & -.051 & .002 & -.086 \\
\hline & $(-2.097)$ & $(-1.027)$ & $(.306)$ & $(-.683)$ & $(-.588)$ & $(.024)$ & $(-.868)$ \\
\hline \multirow{2}{*}{ Prior Training } & .132 & $.253 * * *$ & -.105 & $.241 * *$ & .140 & .115 & -.013 \\
\hline & $(1.465)$ & (2.712) & $(-1.051)$ & (2.618) & $(1.552)$ & (1.229) & $(-.123)$ \\
\hline Training & $\begin{array}{l}.339^{* * *} \\
(3.830)\end{array}$ & $\begin{array}{l}.276^{* * *} \\
(3.014)\end{array}$ & $\begin{array}{l}.330^{* * *} \\
(3.369)\end{array}$ & $\begin{array}{l}.209^{* *} \\
(2.318)\end{array}$ & $\begin{array}{l}.354 * * * \\
(4.011)\end{array}$ & $\begin{array}{l}.289^{* * *} \\
(3.156)\end{array}$ & $\begin{array}{l}.180^{*} \\
(1.787)\end{array}$ \\
\hline $\begin{array}{l}\text { Prior business } \\
\text { start-up } \\
\text { experience }\end{array}$ & $\begin{array}{l}-.080 \\
(-.810)\end{array}$ & $\begin{array}{l}-.120 \\
(-1.182)\end{array}$ & $\begin{array}{l}.161 \\
(1.478)\end{array}$ & $\begin{array}{l}-.046 \\
(-.457)\end{array}$ & $\begin{array}{l}-.027 \\
(-.277)\end{array}$ & $\begin{array}{l}-.082 \\
(-.809)\end{array}$ & $\begin{array}{l}.108 \\
(.968)\end{array}$ \\
\hline $\begin{array}{l}\text { Having Other } \\
\text { business }\end{array}$ & $\begin{array}{l}.193 * * \\
(2.278)\end{array}$ & $\begin{array}{l}.147^{*} \\
(1.673)\end{array}$ & $\begin{array}{l}.090 \\
(.960)\end{array}$ & $\begin{array}{l}.144^{*} \\
(1.668)\end{array}$ & $\begin{array}{l}.246^{* * *} \\
(2.904)\end{array}$ & $\begin{array}{l}.144 \\
(1.638)\end{array}$ & $\begin{array}{l}.215^{* *} \\
(2.231)\end{array}$ \\
\hline $\begin{array}{l}\text { Respondent } \\
\text { Owner }\end{array}$ & $\begin{array}{l}.351^{* * *} \\
(3.719)\end{array}$ & $\begin{array}{l}.253 * * \\
(2.595)\end{array}$ & $\begin{array}{l}.011 \\
(.102)\end{array}$ & $\begin{array}{l}.393^{* * * *} \\
(4.097)\end{array}$ & $\begin{array}{l}.268^{* * *} \\
(2.846)\end{array}$ & $\begin{array}{l}.306^{* * *} \\
(3.137)\end{array}$ & $\begin{array}{l}.024 \\
(.221)\end{array}$ \\
\hline F Statistics & $6.435 * * *$ & $5.134 * * *$ & $2.579 * *$ & $5.731 * * *$ & $6.534 * * *$ & $5.037 * * *$ & 1.738 \\
\hline $\mathrm{R}^{2}$ & 308 & .262 & .152 & .284 & .312 & .259 & .108 \\
\hline Adjusted $\mathrm{R}^{2}$ & .260 & .211 & .093 & .235 & .264 & .207 & .046 \\
\hline
\end{tabular}

Note: Significance level ${ }^{*} \mathrm{p}<0.1,{ }^{* *} \mathrm{p}<0.05,{ }^{* * *} \mathrm{p}<0.01, \mathrm{t}$ values are in parenthesis 
Further, results of Table 2 indicated that overall model of owner/managers background characteristics and EO was not significant. Therefore, background characteristics of owner/managers are not directly influence on EO of the tea manufacturing firms.

\subsection{Entrepreneurial Competencies and EO}

This section includes empirical evidence on the entrepreneurial competencies and EO of tea manufacturing firms in Sri Lanka. Hypothesis $2\left(\mathrm{H}_{2}\right)$ was tested through two stage hierarchical regression analysis and stepwise method was used to identify the competencies which impacted on EO and its dimensions. Firm's size, availability of Green Leaf (GL), ownership and firms in mature stage (Man et al. (2008) found that firms in mature stage have strongest positive impact on performance) were used as control variables in order to focus on proposed relationship. Results of the regression analysis are shown in Table 3.

The results revealed that strategic and commitment competencies were positively and significantly impacted on $\mathrm{EO}$ of the tea manufacturing firms. This implies that entrepreneurs strategic and commitment competencies have direct positive relationship with EO. The entrepreneur needs to be visionary and lay down the direction for the business in order to make sure the long term performance through EO of the firm. Entrepreneur's strategic competency is the curial factor of the above task. Kuratko et al. (1997) found that goal setting and drives are essential for business continuation not only in early phase of the business startup. To sustain the effort, an entrepreneur also required to acquire the commitment competencies outfitting with essential dive and initiatives. According to Ahmad et al. (2010) strong commitment is vital and it keeps entrepreneurs motivated to pursue their business goals regardless of obstacle imposes by the environment. Management literature suggested that the business strategies were influenced by the personal values of owner/managers (Kotey \& Meredith, 1997; Schmidt \& Posner, 1992). Also Man et al. (2002) argued that long term performance of the business firm is depending on the presence of strategic and commitment competencies of entrepreneurs. Further, Man et al. (2008) found that commitment competencies of entrepreneur have significant positive relationship with the performance of the firm.

Table 3. Regression results of entrepreneurial competencies and EO

\begin{tabular}{|c|c|c|c|c|}
\hline & & Dimensions of EO & & \\
\hline & EO Model 1 & $\begin{array}{l}\text { Innovativeness Model } \\
2\end{array}$ & $\begin{array}{l}\text { Proactiveness Model } \\
3\end{array}$ & $\begin{array}{l}\text { Risk } \\
\text { Model } 4\end{array}$ \\
\hline Control variables & & & & \\
\hline Availability of GL & $.077(.823)$ & $.031(.344)$ & $.044(.473)$ & $.117(1.181)$ \\
\hline Size (monthly sales) & & $.112(1.290)$ & & \\
\hline Main Effects & & & & \\
\hline $\begin{array}{l}\text { Opportunity } \\
\text { competencies }\end{array}$ & & & & \\
\hline $\begin{array}{l}\text { Relationship } \\
\text { competencies }\end{array}$ & & & & \\
\hline Concept competencies & & & $.209 * *(2.127)$ & \\
\hline $\begin{array}{l}\text { Organizing } \\
\text { competencies }\end{array}$ & & $.268 * * *(2.733)$ & & \\
\hline Strategic competencies & $.263^{* *}(2.373)$ & $.359 * * *(3.354)$ & & \\
\hline $\begin{array}{l}\text { Commitment } \\
\text { competencies }\end{array}$ & $\begin{array}{l}.320 * * * \\
(3.092)\end{array}$ & & $.329 * * *(3.126)$ & $.284 * * *(2.870)$ \\
\hline F Statistics & $16.663^{* * *}$ & $18.167 * * *$ & $10.776^{* * *}$ & $7.272 * * *$ \\
\hline $\mathrm{R}^{2}$ & .323 & .411 & .235 & .121 \\
\hline Adjusted $\mathrm{R}^{2}$ & .303 & .389 & .214 & .104 \\
\hline Change of $\mathrm{R}^{2}$ & .198 & .253 & .180 & .061 \\
\hline
\end{tabular}

Note: Significance level ${ }^{*} \mathrm{p}<0.1,{ }^{* *} \mathrm{p}<0.05,{ }^{* * *} \mathrm{p}<0.01, \mathrm{t}$ values are in parenthesis 
When considering the dimensions of EO, the results illustrated that organizing and strategic competencies significantly impacted on innovativeness of the tea manufacturing firms. It means owner/manager's competencies of operating various resources through organizing and directing them through proper strategic planning is positively related to the innovation of the firm. This result, consistent with Miller et al. (1982), that is CEOs internal locus of control positively correlate with the firm's tendency of innovation. The results of Table 3 revealed that conceptual and commitment competencies are positive and significantly affected proactiveness of the firm. According to Bird (1995) the conceptual ability of entrepreneur is heavily influenced on the capability of thinking logically and dealing with ambiguity. Therefore, this implies that owner/managers ability of thinking out of box and commitment are highly influence on the competitive behavior directed toward rival firms. Further, results of Table 3 show that commitment competency significantly impacted on risk taking behavior of the firm. Evidently, prior to make business related decisions entrepreneurs evaluate the risk associated with it. Hence, owner/managers committed themselves to accomplish those targets once they made business decisions.

According to the results of Table 3, the changes in $R^{2}$ revealed that main variables of model 1,2 and 3 have noticeably higher impact on dependents than control variables; whereas model's 4 impacts of main variables are comparatively lower. In hypothesis 2 , we predicted that entrepreneurial competencies of owner/manager have positive relationship with the EO of the firm. As explain in above (results of table 3), one or more of following competencies namely conceptual, organizing, and strategic and commitment positively impacted on EO and it dimensions. Therefore $\mathrm{H}_{2}$ is supported. However no impact was found for opportunity and relationship competencies on EO and it dimensions. It can be explained by assumption that these competencies may not eagerly relevant to the conceptualizing of the EO of tea manufacturing firms in Sri Lanka. Since Man et al. (2002) argued that entrepreneur's opportunity and relationship competencies have positive relationship with the competitive scope (external environment) of the business firm. Further, Man et al. (2008) found significant and positive effect of opportunity and relationship competencies on competitive scope. In addition Baum et al. (2001) found that CEOs opportunity recognition skill has an indirect relationship with venture growth.

\section{Conclusion}

This study addressed the owner/manager's entrepreneurial competencies and EO of tea manufacturing firms in Sri Lanka. The findings indicated that background characteristics of owner/managers have direct impact on entrepreneurial competencies. Other findings indicated that entrepreneurial competencies of owner/manager are positively related to the EO and its dimensions. By these findings, basic hypotheses that are proposed in this study are proven.

Among background characteristics, training is positive and significantly affected on all competencies. Therefore, it is important to emphasis on training in order to enhance the entrepreneurial competencies. The finding revealed that in general tea factory owners have higher level of entrepreneurial competencies than managers. In addition, background characteristics of owner/managers do not have direct relationship with EO and it indirectly effect on EO through entrepreneurial competencies.

This study implies that different combinations of entrepreneurial competencies have direct effect on firm's EO and its dimensions. These findings in line with earlier research by Man et al. (2008), they found that commitment competencies of entrepreneur have a direct relationship with performance of the firm. Further results emphasis, comparatively commitment competencies of owner/managers highly impacted on EO and its dimensions. Since, according to Timmons (1978) thriving entrepreneurs are generally observed to have remarkable amount of personal energy and ability to work long hours and high level of confidence. Secondly, impact of strategic competencies on EO and its dimensions is important. Thus, these entrepreneurial competencies can be considered as crucial aspects of entrepreneurship, and they ought to have severe concern in EO. When considering the dimensions of EO, innovativeness was greatly affected by owner/managers competencies whereas risk taking was less likely affected by competencies. Therefore, it can be concluded that enhancing owner/managers competencies would leads to innovativeness and overall $\mathrm{EO}$ of tea manufacturing firms.

However, there are some limitations inherent in this study. The number of sample is relatively small and this research is limited to low country tea industry if we consider generalizing these results and recommendations of the study. Therefore, additional research would complement this research by considering other tea growing regions to enhance the generalizability of these findings. Further, longitudinal study may offer remarkable insights about how owner/mangers entrepreneurial competencies would effect on the EO of tea manufacturing firms. 


\section{Implications}

The present research findings have several inferences for theory and practice mainly for enhancement of tea manufacturing firms in Sri Lanka. Theoretical contribution of this research provides new insight to tea sector research in relation to the tea manufacturing firms in Sri Lanka to follow up related studies in entrepreneurship, which make available more consistent data and interpretations in tea sector development. Further present study enriches the entrepreneurship literature by providing empirical data of significant relationship between owner/managers entrepreneurial competencies and $\mathrm{EO}$ and its dimensions.

It reveals that entrepreneurial competencies are crucial for EO and thereby success of the business firms, consequently these results propose relevant parties such as practitioners and policy makers should facilitate entrepreneurs to develop their own entrepreneurial competencies. Therefore identifying critical factors which enhance entrepreneurial competencies is beneficial for development activities of government and non-government sector. Further identifying important relationships of different competencies and EO and its dimensions will allow a more focused approach to design training programs to entrepreneurs. In fact, the findings point out that it is important to develop competent entrepreneur as similarly providing more resources and a positive environment. Further, the present study may also provide insight for owner/managers of tea manufacturing firms in Sri Lanka to assess their individual level of entrepreneurial competencies. Thereby they can determine their training requirement and it allows them to enhance competencies and adopt appropriate entrepreneurial strategies to mitigate the challenges arising in the global tea market.

\section{References}

Ahmad, N. H., Halim, H. A., \& Zainal, S. R. M. (2010). Is Entrepreneurial Competency the Silver Bullet for SME Success in a Developing Nation? International Business Management, 4(2), 67-75. Retrieved from http://docsdrive.com/pdfs/medwelljournals/ibm/2010/67-75.pdf

Alarape, A. A. (2007). Entrepreneurship programs, operational efficiency and growth of small businesses. Journal of enterprising communities: People and Places in the global economy, 1(3), 222-239. http://dx.doi.org/10.1108/17506200710779530

Baum, J. R., Locke, E. A., \& Smith, K. G. (2001). A multidimensional model of venture growth. Academy of Management Journal, 44(2), 292-303. http://dx.doi.org/10.2307/3069456

Bird, B. (1995). Towards a theory of entrepreneurial competency. Advances in Entrepreneurship, Firm Emergence and Growth, 2, 51-72. Retrieved from http://www.academia.edu/1282975/Toward_a_theory_of_ entrepreneurial_competency

Brinckmann, J. (2008). Competence of top management teams and success of new technology-based firms: A theoretical and empirical analysis concerning competencies of entrepreneurial teams and the development of their ventures. Deutscher Universitäts-Verlag.

Chandler, G. N., \& Hanks, S. H. (1994). Founder competence, the environment and venture performance. Entrepreneurship Theory and Practice, 18(3), 77-98.

Chandler, G. N., \& Jansen, E. (1992). The founder's self-assessed competence and venture performance. Journal of Business Venturing, 7(3), 223-236. http://dx.doi.org/10.1016/0883-9026(92)90028-P

Covin, J. G., \& Slevin, D. P. (1989). Strategic management of small firms in so stile and benign environments. Strategic Management Journal, 10(1), 75-87. http://dx.doi.org/10.1002/smj.4250100107

Covin, J. G., Slevin, D. P., \& Covin, T. J. (1990). Content and performance of growth-seeking strategies: A comparison of small firms in high-and low technology industries. Journal of Business Venturing, 5(6), 391-412. http://dx.doi.org/10.1016/0883-9026(90)90013-J

Cragg, P. B., \& King, M. (1988). Organizational characteristics and small firms' performance revisited. Entrepreneurship Theory and Practice, 13(2), 49-64.

David, F. R. (2013). Strategic management: Concepts and cases: A competitive advantage approach (14th ed.). Boston: Pearson.

Dyke, L. S., Fischer, E. M., \& Reuber, A. R. (1992). An inter-industry examination of the impact of owner experience on firm performance. Journal of Small Business Management, 30(4), 72-87.

Hambrick, D. C. (1981). Environment, strategy, and power within top management teams. Administrative Science Quarterly, 26(2), 253-275. http://dx.doi.org/10.2307/2392472

Harper, M. (1991). The role of enterprise in poor countries. Entrepreneurship, Theory and Practice, 15(4), 7-11. 
Herron, L., \& Robinson, Jr. R. B. (1993). A structural model of the effects of entrepreneurial characteristics on venture performance. Journal of Business Venturing, 8(3), 281-294. http://dx.doi.org/10.1016/0883-9026(93) 90032-Z

Huck, J., \& McEwen, T. (1991). Competencies needed for small business success: Perceptions of Jamaican entrepreneurs. Journal of Small Business Management, 29(4), 90-93.

Knight, G. A. (1997). Cross-cultural reliability and validity of a scale to measure firm entrepreneurial orientation. Journal of business venturing, 12(3), 213-225. http://dx.doi.org/10.1016/S0883-9026(96)00065-1

Kotey, B., \& Meredith, G. G. (1997). Relationships among owner/manager personal values, business strategies, and enterprise performance. Journal of small business management, 35(2), 37-64.

Kreiser, P. M., Marino, L. D., \& Weaver, K. M. (2002). Assessing the psychometric properties of the entrepreneurial orientation scale: A multi-country analysis. Entrepreneurship Theory and Practice, 26(4), 71-94.

Krueger, N. F., \& Brazeal, D. V. (1994). Entrepreneurial potential and potential entrepreneurs. Entrepreneurship Theory and Practice, 18, 91.

Kuratko, D. F., Hornsby, J. S., \& Naffziger, D. W. (1997). An examination of owner's goals in sustaining entrepreneurship. Journal of Small Business Management, 35(1), 24-33.

Lerner, M., \& Almor, T. (2002). Relationships among strategic capabilities and the performance of women-owned small ventures. Journal of Small Business Management, 40(2), 109-125. http://dx.doi.org/10. 1111/1540-627X.00044

Li, X. (2009). Entrepreneurial competencies as an entrepreneurial distinctive: An examination of the competency approach in defining entrepreneurs. Retrieved from http://ink.library.smu.edu.sg/etd_coll/14

Man, T. W. Y. (2001). Entrepreneurial competencies and the performance of small and medium enterprises in the Hong Kong services sector. (PhD dissertation, Hong Kong Polytechnic University). Retrieved from http://repository.lib.polyu.edu.hk/jspui/handle/10397/3532

Man, T. W. Y., Lau, T., \& Chan, K. F. (2002). The competitiveness of small and medium enterprises: A conceptualization with focus on entrepreneurial competencies. Journal of Business Venturing, 17(2), 123-142. http://dx.doi.org/10.1016/S0883-9026(00)00058-6

Man, T. W. Y., Lau, T., \& Snape, E. (2008). Entrepreneurial competencies and the performance of small and medium enterprises: An investigation through a framework of competitiveness. Journal of Small Business \& Entrepreneurship, 21(3), 257-276. http://dx.doi.org/10.1080/08276331.2008.10593424

Maxwell, J. R., \& Westerfield, D. L. (2002). Technological entrepreneurism characteristics related to the adoption of innovative technology. SAM Advanced Management Journal, 67(1), 9-13.

McClelland, D. C. (1965). N achievement and entrepreneurship: A longitudinal study. Journal of Personality and Social Psychology, 1(4), 389-392. http://dx.doi.org/10.1037/h0021956

Miller, D., \& Toulouse, J. M. (1986a). Chief executive Personality and corporate strategy and structure in small firms. Management Science, 32(11), 1389-1409. http://dx.doi.org/10.1287/mnsc.32.11.1389

Miller, D., \& Toulouse, J. M. (1986b). Strategy, structure, CEO personality and performance in small firms. American Journal of Small Business, 10(3), 47-62.

Miller, D., De Vries, M. F. K., \& Toulouse, J. M. (1982). Top executive locus of control and its relationship to strategy-making, structure, and environment. Academy of Management journal, 25(2), 237-253. http://dx. doi.org/10.2307/255988

Mohamed, M. T. Z., \& Zoysa, A. K. N. (2006). Current status and future research focus of tea in Sri Lanka. The Journal of Agricultural Sciences, 2(2), 32-42. Retrieved from http://www.sab.ac.lk/journal_agri/papers/ agri_vol2_2_2006/agri_vol2_2_2006_artical4.pdf

Morris, M., Schindehutte, M., \& Allen, J. (2005). The entrepreneur's business model: Toward a unified perspective. Journal of Business Research, 58(6), 726-735. http://dx.doi.org/10.1016/j.jbusres.2003.11.001

Nunally, J. (1978). Psychometric (2nd ed.). McGraw Hill, New York.

Porter, M. E. (1991). Towards a dynamic theory of strategy. Strategic management journal, 12(S2), 95-117. http://dx.doi.org/10.1002/smj.4250121008 
Schmidt, W. W., \& Posner, B. Z. (1992). The values of American managers then and now. Management Review, 81(2), 37-40.

Schmitt-Rodermund, E. (2004). Pathways to successful entrepreneurship: Parenting, personality, early entrepreneurial competence, and interests. Journal of Vocational Behavior, 65(3), 498-518. http://dx.doi. org/10.1016/j.jvb.2003.10.007

Shane, S., \& Venkataraman, S. (2000). The promise of entrepreneurship as a field of research. Academy of Management Review, 25(1), 217-226.

Stuart, R. W., \& Abetti, P. A. (1990). Impact of entrepreneurial and management experience on early performance. Journal of Business Venturing, 5(3), 151-162. http://dx.doi.org/10.1016/0883-9026(90) 90029-S

Timmons, J. A. (1978). Characteristics and role demands of entrepreneurship. American Journal of Small Business, 3(1), 5-17.

Watanabe, S. (1970). Entrepreneurship in small enterprises in Japanese manufacturing. International Labour Review, 102(6), 105-128. Retrieved from http://heinonline.org/HOL/Page?handle=hein.journals/intlr102 $\&$ div $=55 \&$ g_sent $=1 \&$ collection $=$ journals $\# 546$

Westerberg, M., Singh, J., \& Häckner, E. (1997). Does the CEO matter? An empirical study of small Swedish firms operating in turbulent environments. Scandinavian Journal of Management, 13(3), 251-270. http://dx.doi.org/10.1016/S0956-5221(97)00011-0

\section{Appendix A}

\section{Profile of Respondents and Tea manufacturing Firms}

Table A1. Background characteristics of owner/managers and characteristics of tea manufacturing firms

\begin{tabular}{|c|c|c|}
\hline Characteristics & Frequency & Percentage $(\%)$ \\
\hline \multicolumn{3}{|l|}{ Position of respondent } \\
\hline Owner & 32 & 29.36 \\
\hline Manager & 77 & 70.64 \\
\hline \multicolumn{3}{|l|}{$\begin{array}{l}\text { Present age of Owner/manager } \\
\text { (Years) }\end{array}$} \\
\hline $25-35$ & 19 & 17.43 \\
\hline $36-55$ & 68 & 62.39 \\
\hline $56-65$ & 18 & 16.51 \\
\hline Above 65 & 4 & 3.67 \\
\hline \multicolumn{3}{|l|}{ Level of Education } \\
\hline Ordinary Level (1) & 9 & 8.26 \\
\hline Advance Level (2) & 84 & 77.06 \\
\hline Graduate (3) & 13 & 11.93 \\
\hline Post Graduate (4) & 3 & 2.75 \\
\hline \multicolumn{3}{|l|}{$\begin{array}{l}\text { Training received prior current } \\
\text { position }\end{array}$} \\
\hline Managerial & 27 & 24.77 \\
\hline Technical & 19 & 17.43 \\
\hline Both & 31 & 28.44 \\
\hline Neither & 32 & 29.36 \\
\hline \multicolumn{3}{|l|}{$\begin{array}{l}\text { Training received after current } \\
\text { position }\end{array}$} \\
\hline Managerial & 17 & 15.60 \\
\hline Technical & 10 & 9.17 \\
\hline Both & 17 & 15.60 \\
\hline Neither & 65 & 59.63 \\
\hline
\end{tabular}




\begin{tabular}{lll}
\hline Characteristics & Frequency & Percentage (\%) \\
\hline Prior business start-up experience & 28 & 25.69 \\
Yes & 81 & 74.31 \\
No & 52 & \\
Involvement of other business & 57 & 47.71 \\
Yes & & 52.29 \\
No & 13 & \\
Size (Monthly sales Kg) & 62 & 11.93 \\
$<=25000$ & 24 & 56.88 \\
25 001-75 000 & 10 & 22.02 \\
75 001-100 000 & & 9.17 \\
$>100000$ & 47 & \\
Ownership Structure & 23 & 43.12 \\
Sole proprietorship & 39 & 21.10 \\
Partnerships & & 35.78 \\
Private limited Company & 12 & \\
Stage of business development & 70 & 11.01 \\
Introductory & 23 & 64.22 \\
Growing & 4 & 21.10 \\
Maturity & & 3.67 \\
Declining & & \\
\hline Source: Survey Data 2013 & &
\end{tabular}

Source: Survey Data, 2013

\section{Copyrights}

Copyright for this article is retained by the author(s), with first publication rights granted to the journal.

This is an open-access article distributed under the terms and conditions of the Creative Commons Attribution license (http://creativecommons.org/licenses/by/3.0/). 